\title{
NILAI-NILAI KARAKTER DALAM TINDAK TUTUR ILOKUSI DALAM BUKU WIR BESUCHEN EINE MOSCHEE
}

\author{
Tri Kartika Handayani, Sri Megawati dan Lia Malia \\ FBS Universitas Negeri Yogyakarta \\ email: tri_kartika@uny.ac.id
}

\begin{abstract}
Abstrak
Penelitian ini bertujuan mendeskripsikan: (1) jenis dan bentuk tuturan. (2) fungsi tuturan, dan (3) nilai-nilai karakter yang terdapat dalam tuturan ilokusi dalam buku Wirbesucheneine Moschee (WBM) 'Kami Mengunjungi Mesjid'. Data penelitian ini yaitu semua tuturan yang terdapat dalam WBM. Buku ini adalah salah satu buku bacaan siswa kelas 5 Sekolah Dasar di Jerman. Penelitian ini penelitian deskriptif kualitatif. Penyediaan data menggunakan metode simak bebas libat cakap (SBLC) dan data dianalisis dengan menggunakan metode agih dan padan pragmatis. Dari hasil analisis ditemukan empat jenis tuturan, yaitu asertif, direktif, komisif dan ekspresif. Tiap jenis tuturan memiliki bentuk yang berbeda, yaitu tindak tutur langsung literal, tidak langsung literal, langsung tidak literal, dan tidak langsung tidak literal. Fungsi tuturan dalam buku WBM yaitu tuturan asertif, direktif, komisif dan ekspresif. Nilai-nilai karakter dalam buku WBM ada sepuluh, yaitu religius, toleransi, disiplin, kerja keras, kreatif, demokratis, rasa ingin tahu, menghargai prestasi, bersahabat/komunikatif, dan peduli sosial.
\end{abstract}

Kata kunci: nilai karakter, tuturan ilokusi, buku Wir besuchen eine Moschee

\section{MORAL VALUES IN THE ILLOCUTIONARY SPEECH ACT IN CHILDREN'S BOOK WIR BESUCHEN EINE MOSCHEE}

\begin{abstract}
This study aims to describe: (1) typesand forms of utterances, (2) functions of utterances, and (3) moral values in the illocutionary act in the children's book Wir besuchen eine Moschee (WBM) 'We Visit the Mosque'. The data are all utterances in WBM. The book is one of the textbooks for Grade V students of elementary schools in Germany. This was a qualitative descriptive study. The data were collected by the uninvolved conversation observation technique and analyzed by using the distribution and pragmatic correspondence methods. From the results of the analysis, four types of utterances are found: assertive, directive, commissive, and expressive. Each type of utterance has a different form, namely literal direct, literal indirect, non-literal direct, and non-literal indirect speech acts. The functions of utterances in WBM are assertive, directive, commissive, and expressive. There are ten moral values in WBM, namely religiosity, tolerance, discipline, hard work, creativity, democracy, curiosity, appreciation of achievement, friendship/communication, and social care.
\end{abstract}

Keywords: moral values, illocutionary act, children's book Wir besuchen eine Moschee

\section{PENDAHULUAN}

Dalam kehidupan ini manusia tidak pernah terlepas dari komunikasi antar sesama. Untuk dapat menjalin komunikasi yang baik diperlukan adanya aturan tertentu. Semua tingkah laku dan cara 
berkomunikasi itu merupakan cerminan nilai karakter. Karakter merupakan nilainilai perilaku manusia yang berhubungan dengan Tuhan Yang Maha Esa, diri sendiri, sesama manusia, lingkungan, dan kebangsaan yang terwujud dalam pikiran, sikap, perasaan, perkataan, dan perbuatan berdasarkan norma-norma agama, hukum, tata krama, budaya, dan adat istiadat (Sudrajat, 2010). Suharjana (2011: 46-47) mempertegas pendapat tersebut di atas dengan menyatakan bahwa karakter adalah sebuah cara berpikir, bersikap dan bertindak yang menjadi ciri khas seseorang yang menjadi kebiasaan yang ditampilkan dalam kehidupan bermasyarakat.

Lebih lanjut dapat dicermati bahwa karakter adalah cara berpikir dan berperilaku yang menjadi ciri khas tiap individu untuk hidup dan bekerjasama, baik dalam lingkup keluarga, masyarakat, bangsa dan negara. Individu yang berkarakter baik adalah individu yang bisa membuat keputusan dan siap mempertanggungjawabkan tiap akibat dari keputusan yang dibuatnya (Suyanto, 2010). Agar seseorang memiliki karakter yang baik, maka perlu dilakukan pendidikan karakter. Menurut Marzuki (2011: 471) pendidikan karakter tidak hanya mengajarkan mana yang benar dan mana yang salah kepada anak, tetapi lebih dari itu pendidikan karakter menanamkan kebiasaan tentang yang baik sehingga peserta didik paham, mampu merasakan dan mau melakukan yang baik. Pendidikan karakter pada dasarnya membawa misi yang sama dengan pendidikan moral.

Hal tersebut di atas tidak hanya dijumpai dalam komunikasi lisan saja, tetapi juga dalam buku bacaan, karena dalam buku bacaan tersebut banyak dijumpai tuturan. Searle (via Hoffmann 2000: 143-150) menyatakan bahwa tindak tutur ini terdiri dari tindak tutur lokusi, ilokusi dan perlokusi. Tindak tutur lokusi adalah bentuk tindak tutur untuk menyampaikan atau menyatakansesuatu kepada mitra tutur. Tuturan ini dapat berbentuk pertanyaan, pernyataanatau perintah. Tindak tutur ilokusi merupakan tindak tutur untuk menginformasikan sesuatu dan menyuruh mitra tutur untuk melakukan sesuatu, sedangkan tindaktutur perlokusi merupakan efek atau hasil yang disebabkan dari tuturan itu kepada mitra tuturnya. Mitra tutur melaksanakan atau apa yang dikehendaki penutur.

Berikut ini adalah satu contoh tindak tutur dalam bahasa Jerman.

(1) Uh, es zieht hier in diesem Raum.

'Hu, dingin sekali di ruangan ini'.

Tuturan di atas diungkapkan seorang tamu di keluarga Jerman pada saat musim dingin.Tindak tutur lokusinya berupa modus pernyataan dari penutur (tamu) untuk menyatakan keadaan cuaca yang sesungguhnya memang sangat dingin. Mitra tutur yang mendengar tuturan tersebut memberikan jawaban sebagai berikut.

(2) Zieh deine Jacke an!

'Pakai jaketmu'!

(3) Soll ich die Heizung höher anstellen?

'Perlukah temperatur ruangan saya naikkan?

(4) Möchtest du Tee trinken?

'Mau minum Teh?'

Penutur mengatakan kepada mitra tutur Uh, es zieht hier in diesem Raum. 'Hu, dingin sekali di ruangan ini', untuk mengungkapkan keadaan yang sesungguhnya. Tetapi mitra tutur memberikan beberapa alternatif reaksi atas tuturan tersebut, karena tuturan (1) tersebut dapat bermakna permintaan kepada mitra tutur untuk mengambilkan jaket (2), untuk menaikkan temperatur pemanas ruangan (3) dan menyuruh mitra tutur untuk membuatkan minuman teh panas (4). Bila mitra tutur melakukan salah satu tindakan mengambilkan jaket, menaikkan temperatur pemanas ruangan atau membuat- 
kan minuman teh panas, maka tindakan ini disebut tindak perlokusi, yaitu efek yang ditimbulkan dari tuturan itu. Tuturan tersebut merupakan contoh tuturan ilokusi dalam bahasa Jerman yang dikaji dalam penelitian ini.

Dalam penelitian ini juga dikaji tentang muatan nilai-nilai karakter dari tindak tutur ilokusi bahasa Jerman yang terdapat dalam buku bacaan anak WBM. Permasalahan ini sangat layak untuk dikaji, karena tuturan antara para siswa dalam buku bacaan ini mengandung nilainilai karakter. Secara praktis, kajian ini bermanfaat untuk mengembangkan pembelajaran bahasa Jerman melalui pengenalan tuturan-tuturan pragmatis yang mengandung nilai-nilai karakter dalam budaya Jerman.

Searle (via Hoffmann 2000: 143-150) mengklasifikasikan tindak ilokusi (illokutionärer Akt) dalam lima jenis, sebagai berikut. Pertama, tindak ilokusi asertif/ representatif menurut Buâmann (2008: 673) die Intention des Sprechers istes, sich auf die Wahrheit der ausgedrückten Proposition festzulegen. Hal ini berarti bahwa maksud penutur terikat dengan kebenaran proposisi yang telah diungkapkan, seperti berpendapat, mengidentifikasi, melaporkan, menyatakan, mengeluh. Kedua, tindak ilokusi direktif bertujuan supaya mitra tutur menghasilkan suatu tindakan yang diinginkan oleh penutur. Tindak tutur direktif ini bisa berupa memesan, meminta, memerintah, menasehati, bertanya, dan menuntut. Ketiga, pada ilokusi komisif penutur terikat pada suatu tindakan di masa mendatang. Tindakan di masa mendatang ini meliputi berjanji, mengancam, bersumpah, menawarkan. Keempat, tindak ilokusi ekspresif mengutarakan sikap psikologis penutur terhadap keadaan yang terungkap dalam ilokusi. Tindak ilokusi ekspresif ini berupa mengucapkan selamat, berbelasungkawa, meminta maaf, berterimakasih, memuji, mengucapkan selamat, dan penyambutan. Kelima, dalam ilokusi deklarasi ini keberhasilan pelaksanaan ilokusi ini akan mengakibatkan adanya kesesuaian antara isi proposisi dengan kenyataan. Ilokusi deklaratif ini berupa membaptis, menyatakan perang, memecat, menghukum dan sebagainya. Tindak tutur ini adalah tindak tutur yang mengubah dunia melalui tuturannya, contohnya: pernyataan seorang pendeta di gereja ketika membaptis seorang anak.

(7) "Ich taufe dich auf den Namen Angelika."

'Saya membaptis kamu dengan nama Angelika.' (Linke,1996:183)

Berdasarkan penjelasan tersebut di atas, fokus penelitian ini dapat dirumuskan sebagai berikut. Pertama, jenis dan bentuk tuturan yang terdapat dalam buku WBM. Kedua, fungsi tuturan dalam buku WBM tersebut. Ketiga, nilai-nilai karakter yang diungkapkan tuturan dalam buku WBM. Penelitian ini perlu dilakukan karena dalam buku WBM banyak ditemukan beberapa bentuk dan fungsi tuturan, dan dalam tuturan tersebut mengandung aspek kebahasaan yang bersifat pragmatis yang berkaitan dengan nilai-nilai karakter. Unsur pragmatik ini sangat penting untuk diajarkan, agar nantinya pembelajar bahasa Jerman dapat berkomunikasi dalam bahasa Jerman dengan baik. Apabila pragmatik ini tidak dikuasai dengan baik, maka dalam komunikasi akan terdapat berbagai ketimpangan yang tidak diharapkan.

\section{METODE}

Penelitian ini merupakan penelitian deskriptif kualitatif. Sumber penelitian ini yaitu buku bacaan Wir besuchen eine Moschee. Data penelitiannya yaitu tuturan ilokusi dan semua tuturan yang mengandung muatan nilai karakter. Data penelitian ini berupa dialog antara para siswa Sekolah Dasar yang berusia antara 9-10 tahun. Bilal seorang siswa berkebangsaan Turki beragama Islam, Sebastian beragama 
Katolik dan Katharina Kristen Ortodoks. Tokoh pendamping yaitu Ibrahim Bey seorang imam mesjid di Derendorf berkebangsaan Turki. Buku ini merupakan salah satu buku bacaan di Jerman dengan pembelajaran interkulturel berbasis keragaman agama yang diterbitkan oleh institut untuk Sekolah dan Pendidikan Lanjutan Negara bagian Nordrhein-Westfalen.

Pada tahap penyediaan data digunakan metode Simak Bebas Libat Cakap (SBLC) (Sudaryanto 1993: 133). Dalam pengumpulan data, peneliti membaca dengan seksama semua data tindak tutur ilokusi antara para siswa yang terdapat dalam buku WBM. Agar mendapatkan pemahaman yang ajeg, masing-masing anggota penelitimembaca buku tersebut sebanyak tiga kali. Kemudian semua peneliti berdiskusi untuk menyamakan persepsi, sehingga diperoleh pemahaman dan pemaknaan yang sama.

Data dianalisis dengan menggunakan metode agih dan padan pragmatis. Menurut Sudaryanto (1993: 205-206) metode agih merupakan metode analisis bahasa yang alat penentunya merupakan bagian dari bahasa itu sendiri. Metode padan pragmatis adalah metode analisis bahasa yang alat penentunya ada di luar, dan tidak menjadi bagian dari bahasa. Metode agih digunakan untuk menganalisis bentuk-bentuk tuturan. Metode padan pragmatis digunakan untuk menganalisis fungsi, makna semua tuturan dalam data penelitian

Tahap berikutnya adalah mengelompokkan data. Data diklasifikasikan berdasarkan (1) jenis tuturan, (2) fungsi dan bentuk tuturan dan (3) nilai karakter yang terkandung dalam tuturan tersebut. Semua data tuturan ilokusi dikelompokkan lagi dalam tuturan asertif, direktif, komisif dan ekspresif. Setelah itu setiap kelompok diklasifikasikan lagi dalam bentuk (1) tindak tutur langsung literal, (2) tindak tutur tidak langsung literal, (3) tindak tutur langsung tidak literal, dan (4) tindak tutur tidak langsung tidak literal. Berdasarkan fungsinya setiap tuturan diklasifikasikan berdasarkan maksud dari penutur dan mitra tutur dan makna dari tuturan tersebut. Pendeskripsian data penelitian dilakukan pada tahap akhir. Untuk validitas data dilakukan dengan diskusi antar anggota peneliti dan dengan native speaker yang sekaligus berperan sebagai expert judment.

\section{HASIL DAN PEMBAHASAN Bentuk Tuturan}

Dalam buku WBM ditemukan empat bentuk tuturan, yakni (a) tuturan asertif, (b) tuturan direktif, (c) tuturan komisif, dan tuturan ekspresif. Uraian terperinsi sebagai berikut.

\section{Tuturan Asertif}

Pada tuturan asertif ditemukan tiga kategori, yaitu (a) tindak tutur langsung literal (direkte wörtliche strategie), (b) tindak tutur tidak langsung literal (indirekte wörtliche strategie), (c) tindak tutur tidak langsung tidak literal (indirekte nichtwörtliche strategie). Masing-masing klasifikasi tuturan asertif diuraikan berikut ini.

Pertama, tindak tutur langsung literal (direkte wörtliche strategie). Tindak tutur langsung literal dalam tuturan asertif merupakan tindak tutur yang dipergunakan oleh penutur untuk menyampaikan maksud tuturan dengan modus tuturan dan makna yang sama dengan maksud penyampaiannya, misalnya: menyatakan sesuatu kepada orang lain, melaporkan atau mengidentifikasi dengan menggunakan kalimat berita. Hal tersebut terlihat dalam contohberikut.

Bilal: UnsereMoscheenkannjederbesuchen, egalwelchenGlaubener hat.

'Siapapun boleh mengunjungi mesjid kami, tidak peduli apapun agamanya'.

Konteks: Bilal dan Sebastian sedang di sekolah dan mereka berdiskusi tentang 
keberadaan mesjid di Jerman. Bilal mengatakan kepada Sebastian, kalau di Jerman banyak sekali mesjid. Sebastian sangat penasaran dan dengan serius dia mengatakan kepada Bilal, bahwa dia ingin mengunjungi mesjid di Jerman, tetapi dia beragama Katolik. Bilal menyatakan kepada Sebastian, tidak masalah meskipun dia beragama Katolik, karena agama selain Islam boleh mengunjungi mesjid.

Kedua, tindak tutur tidak langsung literal (indirekte wörtliche strategie). Tindak tutur ini diungkapkan dengan modus yang tidak sesuai dengan maksud penyampaiannya, tetapi makna kata-kata yang menyusunnya sama dengan makna kata yang dimaksudkan penuturnya, misalnya untuk melaporkan biasanya menggunakan kalimat berita, tetapi menggunakan modus kalimat perintah. Berikut contohnya.

Katharina: (zeigt) Seht mal! Dort ist Ibrahim Bey!

'(menunjuk) Lihatlah! Itu Ibrahim Bey!'

Konteks: Sebastian, Katharina dan Bilal berada di mesjid menjelang sholat Jum'at. Katharina berseru kepada Sebastian dan Bilal, tentang apa yang dilihat,: (zeigt) Seht mal! Dort ist Ibrahim Bey!" (menunjuk) Lihatlah! Itu Ibrahim Bey!'.

Tuturan asertif untuk melaporkan sesuatu biasanya menggunakan kalimat berita. Dalam hal ini modus kalimat tidak sesuai dengan maksud pengutaraannya yaitu dengan menggunakan modus kalimat perintah.

Ketiga, tindak tutur tidak langsung tidak literal (indirekte nichtwörtliche Strategie). Tindak tutur ini diungkapkan dengan modus yang tidak sesuai dengan maksud penyampaiannya, kata-kata yang menyusunnya juga tidak sama dengan makna kata yang dimaksudkan penuturnya, tetapi maksud pengutaraannya sama, contohnya:

Bilal: (froh und zufrieden) 'merasa senang dan puas'
Konteks: Dalam perjalanan pulang dari mesjid menuju sekolah, Bilal menatap wajah Sebastian dan Katharina, karena mereka terdiam. Katharina tiba-tiba mengatakan: Das war wirklich total super, Bilal! 'Tadi itu hebat banget, Bilal!'. Sebastian sangat penasaran: Ich hab keine Frauen gesehen. '(ingin tahu) Aku tidak melihat seorang perempuanpun.' Atas ungkapan Katharina dan Sebastian, Bilal merasa sangat senang dan puas karena memiliki pengalaman untuk mengunjungi mesjid. Perasaan ini diungkapkan dengan gestik dan mimik.

Tuturan tersebut tidak diungkapkan dengan modus apapun (diungkapkan dengan ekspresi yang sepadan dengan maksud tuturan), kata-kata penyusunnya tidak diungkapkan dengan kata-kata, tetapi melalui gestik dan mimik, sedangkan maksud penuturnya sama (menyatakan perasaan senang dan puas).

\section{Tuturan Direktif}

Pada tuturan direktif ditemukan dua jenis, yaitu (a) tindak tutur langsung literal (direkte wörtliche strategie), dan (b) tindak tutur tidak langsung literal (indirekte wörtliche strategie). Masing-masing klasifikasi tuturan asertif diuraikan berikut ini.

Pertama, tindak tutur langsung literal (direkte wörtliche Strategie). Tindak tutur ini digunakan oleh penutur untuk menyampaikan maksud tuturan dengan modus tuturan dan makna yang sama dengan maksud penyampaiannya, misalnya: meminta sesuatu kepada orang lain, memerintah, menuntut, memohon atau bertanya dengan menggunakan kalimat berita. Contohnya :

(mit Ernst) Ich würde mir gern mal eine Moschee anschauen.

('dengan serius) Aku ingin sekali mengunjungi mesjid'.

Konteks: Bilal dan Sebastian sedang di sekolah dan mereka berdiskusi ten- 
tang keberadaan mesjid di Jerman. Bilal mengatakan kepada Sebastian, kalau di Jerman banyak sekali mesjid. Sebastian sangat penasaran dan dengan serius dia mengatakan kepada Bilal, bahwa dia ingin mengunjungi mesjid di Jerman.

Data di atas merupakan tuturan direktif dalam bentuk tuturan langsung literal, karena modus kalimat sesuai dengan maksud pengutaraannya yaitu dengan menggunakan modus kalimat perintah dan makna kata-kata yang meminta yang dimaksudkan penuturnya.

Kedua, tindak tutur tidak langsung literal (indirekte wörtliche Strategie). Tindak tutur ini diungkapkan dengan modus yang tidak sesuai dengan maksud penyampaiannya, tetapi makna kata-kata yang menyusunnya sama dengan makna kata yang dimaksudkan penuturnya, misalnya untuk memerintah yang biasanya diungkapkan dengan kalimat perintah, dinyatakan dengan modus kalimat yang lain, misalnya dengan kalimat berita atau kalimat tanya bentuk Konjunktiv II. Penggunaan tindak tutur tidak langsung yang bermakna perintah, yang secara pragmatis dilakukan dengan tuturan dalam bentuk kalimat tanya atau berita, salah satunya dimaksudkan untuk menciptakan kesantunan berkomunikasi. Sebagai contoh dapat dilihat dalam data berikut ini.

Katharina: Wir sollten uns Notizen machen!

'Kita harus mencatat!'

Konteks: Sebastian dan Bilal meninggalkan mesjid dan kembali ke sekolah. Dalam perjalanan ke sekolah Sebastian menyampaikan keheranannya dan bertanya: Aku tidak melihat seorang perempuanpun.

\section{Tuturan Komisif}

Pada tuturan komisif ditemukan dua jenis, yaitu (a) tindak tutur langsung literal (direkte wörtliche strategie), dan (b) tindak tutur tidak langsung literal (indirekte wörtliche strategie). Masing-masing klasifikasi tuturan asertif diuraikan berikut ini.

Pertama, tindak tutur langsung literal (direkte wörtliche Strategie). Tindak tutur inidipergunakan oleh penutur untuk menyampaikan maksud tuturan dengan modus tuturan dan makna yang sama dengan maksud penyampaiannya, misalnya: berjanji, mengancam, bersumpah ataupun menawarkan sesuatu kepada orang laindengan menggunakan kalimat berita atau kalimat perintah. Hal tersebut dapat diperjelas dalam contoh berikut ini.

Bilal: Aber Sebastian! Da brauchst du keine Angst zu haben!

'Tapi Sebastian! Kamu tidak perlu khawatir!'

Konteks: Sebastian dan Bilal sedang ngobrol di sekolah. Bilal bercerita, bahwa di Jerman terdapat banyak mesjid. Sebastian tertarik untuk mengunjungi mesjid tetapi khawatir tidak diperbolehkan. Bilal memberi jaminan dengan mengatakan, Sebastian! kamu tidak perlu khawatir.

Contoh di atas merupakan tuturan komisif dalam bentuk tuturan langsung literal. Modus kalimat sesuai dengan maksud pengutaraannya yaitu dengan menggunakan modus kalimat perintah. Tuturan di atas menyatakan jaminan atau janji.

Kedua, tindak tutur tidak langsung literal (indirekte wörtliche Strategie). Tindak tutur dalam tuturan komisif ini adalah tindak tutur yang diungkapkan dengan modus yang tidak sesuai dengan maksud penyampaiannya, tetapi makna kata-kata yang menyusunnya sama dengan makna kata yang dimaksudkan penuturnya, misalnya untuk berjanji yang biasanya diungkapkan dengan kalimat perintah, dinyatakan dengan modus kalimat yang lain, misalnya dengan kalimat berita atau kalimat tanya bentuk Konjunktiv II. Dalam penelitian ini tidak ditemukan tindak tutur tidak langsung literal komisif. 


\section{Tuturan Ekspresif}

Pada tuturan asertif ditemukan tiga jenis, yaitu (a) tindak tutur langsung literal (direkte wörtliche strategie), (b) tindak tutur tidak langsung literal (indirekte wörtliche strategie), dan (c) tindak tutur tidak langsung tidak literal (indirekte nichtwörtliche strategie). Masing-masing klasifikasi tuturan asertif diuraikan berikut ini.

Pertama, tindak tutur langsung literal (direkte wörtliche Strategie). Tindak tutur dalam tuturan ekspresif ini merupakan tindak tutur yang dipergunakan oleh penutur untuk menyampaikan maksud tuturan dengan modus tuturan dan makna yang sama dengan maksud penyampaiannya, misalnya: berterimakasih, mengucapkan salam, memuji, menyambut ataupun menyetujui. Penyampaian hal tersebut di atas kepada orang lain menggunakan kalimat berita atau kalimat tanya, contohnya:

Bilal: Na klar! Frauen dürfen genauso in die Moschee wie die Männer.

'Tentu saja! Sama seperti anak lakilaki, anak perempuan juga boleh masuk mesjid'.

Konteks: Dalam data tersebut, Sebastian dan Bilal sedang berdiskusi di sekolah. Sebastian kagum dan tidak percaya dan menyangka kalau di Jerman terdapat begitu banyak mesjid. Dia ingin mengunjungi mesjid tersebut dan meminta persetujuan Bilal, dengan bertanya, apakah dia boleh mengajak teman perempuannya. Bilal menjawab 'Tentu saja! Sama seperti anak laki-laki, anak perempuan juga boleh masuk mesjid'.

Kedua, tindak tutur tidak langsung literal (indirekte wörtliche Strategie). Tindak tutur dalam tuturan ekspresif ini adalah tindak tutur yang diungkapkan dengan modus yang tidak sesuai dengan maksud penyampaiannya, tetapi makna kata-kata yang menyusunnya sama dengan makna kata yang dimaksudkan penuturnya. Dalam penelitian ini tidak ditemukan tindak tutur tidak langsung literal ekspresif.
Konteks: Sebastian dan Bilal sedang ngobrol di sekolah. Bilal bercerita, bahwa di Jerman terdapat banyak mesjid. Sebastian tidak mengira kalau di Jerman terdapat begitu banyak mesjid. Dia mengungkapkan keheranan dan pujiannya dengan mengatakan, 'Sungguh?! Itu hebat!'

Data di atas merupakan tuturan ekspresif berupa pujian, yang disampaikan Sebastian kepada Bilal Wirklich?! Das ist ja Irre! Pujian tersebut disampaikan dengan modus kalimat tanya dan modus kalimat berita.

Ketiga, Tindak Tutur Langsung Tidak Literal (direkte nichtwörtliche Strategie). Tindak tutur ini diungkapkan dengan modus yang tidak sesuai dengan maksud penyampaiannya, kata-kata yang menyusunnya juga tidak sama dengan makna kata yang dimaksudkan penuturnya, tetapi maksud pengutaraannya sama. Berikut contohnya.

Sebastian: Wirklich?! Das ist ja Irre! 'Sungguh?! Itu hebat!'

Konteks: Sebastian dan Bilal sedang ngobrol di sekolah. Bilal bercerita, bahwa di Jerman terdapat banyak mesjid. Sebastian tidak mengira kalau di Jerman terdapat begitu banyak mesjid. Dia mengungkapkan keheranan dan pujiannya dengan mengatakan, 'Sungguh?! Itu hebat!'

Tuturan di atas merupakan tuturan ekspresif berupa pujian, yang disampaikan Sebastian kepada Bilal: Wirklich?! Das ist ja Irre!Pujian tersebut disampaikan dengan modus kalimat tanya dan modus kalimat berita.

\section{Fungsi Tuturan \\ Fungsi Tuturan Asertif}

Tuturan asertif yang diperoleh dari data penelitian sebanyak dua puluh lima data. Tuturan ini mempunyai fungsi untuk menyatakan, menyarankan, mengeluh, melaporkan dan mengidentifikasi.

Pertama, fungsi menyatakan jumlah data tuturan aseritif yang mempunyai 
fungsi untuk menyatakan ada lima belas data. Fungsi menyatakan ini meliputi: menyatakan pengakuan agama, tidak sendirian, seorang imam mesjid, peraturan bagi muslimah untuk masuk mesjid, pengakuan keadaan, kemampuan dan mengungkapkan perasaan. Berikut ini salah satu contoh fungsi tuturan asertif untuk menyatakan kemampuan dari Sebastian.

Katharina: Sebastian! Du bist der Künstler! 'Sebastian!Kamukan seniman!'

Konteks tuturan tersebut di atas dapat dijelaskan sebagai berikut $\mathbf{S}$ (Setting dan scene): di mesjid menjelang sholat jum'at, $\mathbf{P}$ (Participant): dalam tuturan di atas Bilal, Katharina dan Sebastian, E (Ends): menyatakan kemampuan Sebastian, A (Act sequence): membicarakan tentang kemampuan Sebastian yang sangat pandai menggambar atau melukis, $\mathbf{K}(\mathrm{Key})$ : situasi gelisah khawatir kalau lupa dan pernyataan spontan Katharina, I (Instrumentalities): bahasa lisan dan bahasa isyarat (sambil menunjuk), $\mathbf{N}$ (Norms): menyatakan apresiasi yang tinggi atas kemampuan Sebastian, G (Genre): menyatakan pengakuan kemampuan.

Kedua, fungsi menyarankan. Fungsi tuturan asertif untuk menyarankan ada tiga data. Berikut ini salah satu tuturan asertif yang bertujuan untuk menyatakan menyarankan.

Katharina: Das sollten die anderen auch mal erleben!!

'Yang lain juga harus tahu itu!!'.

Tuturan tersebut merupakan tuturan asertif untuk menyarankan. Hal ini dapat dipahami melalui komponen tuturan yang menyertainya, yaitu S: dalam perjalanan ke sekolah dari mesjid, P: dalam tuturan ini Katharina kepada Bilal dan Sebastian, E: menyarankan kepada Sebastian dan Bilal, A: memberi ide kepada Sebastian dan Bilal supaya teman-teman yang lain juga bisa mengunjungi mesjid, K: suasana senang dan puas bisa mengunjungi mesjid, I: bahasa lisan berupa tuturan, $\mathbf{N}$ : menyatakan apresiasi yang tinggi, bila saran Katharina bisa diterima, G: menyatakan saran untuk Sebastian dan Bilal.

Ketiga, fungsi mengeluh. Jumlah data untuk fungsi mengeluh ada tiga. Berikut salah satu contohnya.

Sebastian: (konfus) Ich kann mir das alles nicht merken.

'(bingung) aku tidak bisa mengingat semuanya!'

Berdasarkan fungsinya, tuturan asertif yang ditemukan dalam penelitian ini sebanyak dua puluh lima data. Tuturan ini mempunyai fungsi untuk menyatakan, menyarankan, mengeluh, melaporkan dan mengidentifikasi.

Keempat, fungsi melaporkan. Jumlahfungsi tuturan asertif untuk melaporkan ada dua data. Salah satu tuturan tersebut yaitu:

Bilal: (flüster) Das ist der Gebetsruf. Jetzt beginnt das Freitagsgebet.

'(berbisik) Itu panggilan sholat. Sekarang sholat Jum’at dimulai.'

Tuturan di atas merupakan tuturan asertif untuk melaporkan. Komponen tuturannya yaitu $\mathrm{S}$ : di mesjid menjelang sholat Jum'at, P: Bilal berbicara kepada Katharina dan Sebastian, E: Bilal mengatakan kepada Katharina dan Sebastian bahwa itu adalah panggilansholat Jum'at, A: melaporkan situasi menjelang sholat Jum'at, K: dengan perasaan bangga,I: gestik (suara adzan) dan bahasa lisan, $\mathbf{N}$ : memberitahu waktu sholat Jum'at tiba, G: melaporkan kepada mereka sholat Jum'at dimulai.

Kelima, fungsi mengidentifikasi. Jumlah data fungsi tuturan asertif untuk mengidentifikasi sebanyak dua data. Salah satu fungsi tuturan asertif tersebut yaitu sebagai berikut. 
Bilal: In Deutschland gibt es über 2000 Moscheen.

'Di Jerman terdapat lebih dari 2000 mesjid.'

Tuturan di atas salah satu tuturan asertif untuk mengidentifikasi. Hal ini dapat dilihat dari komponen tuturannya, yaitu S:di sekolah menjelang kunjungan ke mesjid, P: Bilal berdiskusi dengan Sebastian, E: mendiskusikan tentang jumlah mesjid di Jerman, A: mengidentifikasi jumlah mesjid di Jerman, K: situasi diskusi, I: bahasa lisan, N: memberi apresiasi yang tinggi tentang jumlah mesjid di Jerman, G: memberitahu Sebastian jumlah mesjid di Jerman.

\section{Fungsi Tuturan Direktif}

Berdasarkan fungsinya, ditemukan sebanyak tujuh tuturan direktif yang terbagi ke dalam lima fungsi tuturan, yakni meminta, memerintah, menuntut, memohon dan bertanya. Dari kelima fungsi tersebut di atas, tuturan yang muncul dalam WBM hanya fungsi tuturan yang menyatakan meminta dan bertanya.

Pertama, fungsi meminta. Jumlah data tuturan direktif yang mempunyai fungsi untuk meminta ada tiga data. Fungsi meminta ini meliputi: permintaan ingin mengunjungi mesjid, permintaan untuk masuk ke dalam mesjid dan melihat-lihat isinya, serta permintaan untuk membuat catatan. Berikut ini salah satu contoh fungsi tuturan direktif meminta, berupa permintaan ijin Sebastian kepada Bilal untuk dapat melihat mesjid.

Sebastian: (mit Ernst) Ich würde mir gern mal eine Moschee anschauen.

'(dengan serius) Aku ingin sekali mengunjungi mesjid.'

Tuturan di atas salah satu tuturan direktif untuk meminta. Hal ini dapat dilihat dari komponen tuturannya, yaitu S: di sekolah menjelang kunjungan ke mesjid, P: Sebastian menyatakan kepada Bilal bahwa ia ingin mengunjungi mesjid, E:agar Bilal mengetahui keinginan Sebastian untuk mengunjungi mesjid, A: menyatakan tentangkeinginannya untuk mengunjungi mesjid, K: penyampaian informasi mengenai keinginan Sebastian mengunjungi mesjid, I: bahasa lisan, $\mathbf{N}$ : menyampaikan permintaan untuk melihat mesjid di Jerman, G: meminta persetujuan untuk melihat mesjid di Jerman.

Kedua, fungsi bertanya. Jumlah data tuturan direktif yang mempunyai fungsi untuk bertanya ada empat data. Fungsi bertanya inimeliputi: pertanyaan apakah di dalam mesjid orang harus berlutut, apakah perempuan boleh masuk ke dalam mesjid, pertanyaan mengenai kesan terhadap mesjid, dan pertanyaan mengapa di mesjid tidak terlihat perempuan. Berikut ini salah satu contoh fungsi tuturan direktif bertanya, berupa pertanyaan Sebastian terhadap Bilal tentang keharusan berlutut di mesjid.

Sebastian: Muß man da knien? oder auch leise sein?

'Haruskah orang di sana (di dalam mesjid) berlutut? Atau tidak boleh ribut?'

Tuturan di atas salah satu tuturan direktif untuk bertanya. Hal ini dapat dilihat dari komponen tuturannya, yaitu S: di sekolah menjelang kunjungan ke mesjid, P: Sebastian bertanya kepada Bilal apakah orang harus berlutut dan tidak boleh rebut di dalam mesjid, E: agar Sebastian mengetahui etika yang harus diperhatikan apabila orang mengunjungi mesjid, A: Sebastian menanyakan mengenai aturan yang berlaku di mesjid, K: Sebastian serius dan merasa khawatir apabila ia melanggar tata aturan yang berlaku di mesjid, I: bahasa lisan berupa kalimat tanya, $\mathbf{N}$ : mengajukan pertanyaan mengenai aturan yang berlaku di mesjid, G: bertanya mengenai tata tertib jika masuk ke mesjid. 


\section{Fungsi Tuturan Komisif}

Tuturan ini mempunyai fungsi untuk berjanji, mengancam, bersumpah dan menawarkan. Dari ke empat fungsi tersebut, dalam penelitian ini hanya ditemukan dua data fungsi berjanji dan satu data fungsi menawarkan.

Pertama, fungsi berjanji. Jumlah data tuturan komisif yang mempunyai fungsi untuk berjanji ada dua data. Fungsi berjanji ini meliputi berjanji dan meyakinkan Sebastian agar ia tidak merasa khawatir, dan berjanji kepada Sebastian bahwa ia akan bertanya kepada ayahnya, dan ayahnya akan bertanya kepada paman Bilal. Berikut ini salah satu contoh fungsi tuturan komisif berjanji, berupa janji Bilal kepada Sebastian.

Bilal: ..., Ich spreche mit meinem Vater und der spricht mit meinem Onkel, ... . ..., 'Aku bicara dengan ayahku dan dia bicara dengan pamanku... .'

Tuturan di atas salah satu tuturan komisif untuk berjanji. Hal ini dapat dilihat dari komponen tuturannya, yaitu $\mathbf{S}$ : di sekolah sebelum kunjungan ke mesjid, P: Bilal berjanji pada Sebastian bahwa ia akan berbicara dengan ayahnya dan ayahnya akan berbicara dengan paman Bilal, E: agar Sebastian merasa yakin bahwa ia akan mendapat ijin untuk mengajak Katharina mengunjungi mesjid, A: Sebastian menanyakan mengenai aturan yang berlaku di mesjid, K: Bilal serius berjanji kepada Sebastian agar Sebastian mendapat kepastian boleh tidaknya mengajak Katharina, I: bahasa lisan berupa kalimat berita, $\mathbf{N}$ : berjanji, G: berjanji untuk memberi kepastian kepada Sebastian mengenai ijin mengajak Katharina mengunjungi mesjid.

Kedua, menawarkan. Jumlah data tuturan komisif yang mempunyai fungsi untuk menawarkan ada satu data. Fungsi menawarkan ini dipakai untuk meminta ijin mengajak Katharina berkunjung ke masjid, contohnya:
Sebastian: (mit Freude) Sag mal, Bilal, können wir nicht auch wie Katharina mitnehmen?

'(dengan gembira) Katakan Bilal, bolehkah kami juga mengajak Katharina?'

Tuturan di atas salah satu tuturan komisif untuk menawarkan. Hal ini dapat dilihat dari komponen tuturannya, yaitu S: di sekolah sebelum kunjungan ke mesjid, P: Sebastian mengajukan pertanyaan apakah ia boleh mengajak Katharina mengunjungi mesjid, E: agar Sebastian merasa yakin bahwa ia boleh mengajak Katharina mengunjungi mesjid, A: Sebastian menanyakan tentang keinginannya mengajak Katharina mengunjungi mesjid, K: dengan perasaan bahagia Sebastian mengutarakan keinginannya mengajak Katharina, I: bahasa lisan berupa kalimat tanya, N: mengajukan tawaran, G: Sebastian menawarkan untuk mengajak Katharina turut serta mengunjungi mesjid.

\section{Fungsi Tuturan Ekspresif}

Berdasarkan fungsinya, ditemukan tiga tuturan ekspresif, yakni memuji, menyambut, dan menyetujui.

Pertama, fungsi memuji. Tuturan ekspresif yang berfungsi untuk memuji ada tiga. Fungsi memuji ini dipakai Sebastian untuk menyatakan pujian kepada Bilal atas informasi yang diberikannya, bahwa di Jerman terdapat lebih dari 2000 mesjid. Berikut ini salah satu contoh fungsi tuturan ekspresif memuji.

Sebastian: Wirklich?! Das ist ja Irre! 'Sungguh?! Itu hebat sekali!'

Hal ini dapat dilihat dari komponen tuturannya, yaitu S: di sekolah sebelum kunjungan ke mesjid, P: Sebastian mengutarakan pujian kepada Bilal, E: sebagai ungkapan rasa takjub Sebastian atas banyaknya mesjid yang terdapat di Jerman, A: berupa pujian, K: dengan perasaan takjub, I: disampaikan secara lisan dalam 
bentuk kalimat tanya, $\mathbf{N}$ : menyatakan pujian, G: Sebastian memuji betapa banyaknya mesjid di Jerman.

Kedua, fungsi menyambut. Jumlah data tuturan ekspresif yang mempunyai fungsi untuk menyambut ada satu data. Fungsi menyambut ini dipakai Imam Bey untuk menyambut anak-anak yang berkunjung ke masjid, misalnya: Imam Bey: "Herzlich Willkommen. 'Selamat datang.'

Hal ini dapat dilihat dari komponen tuturannya, yaitu S: di mesjid ketika anakanak baru datang menjelang sholat Jumat, P: Ibrahim Bey dan anak-anak yang mengunjungi mesjid, E: sebagai ungkapan selamat datang, A: berupa sambutan selamat datang, K: dengan perasaan gembira, I: disampaikan secara lisan dengan kalimat berita, N: menyambut tamu, G: Imam Bey menyambut anak-anak yang mengunjungi mesjid.

Ketiga, fungsi menyetujui. Tuturan ekspresif yang mempunyai fungsi untuk menyetujui ada lima. Fungsi menyetujui ini dipakai oleh Bilal kepada Sebastian ketika Sebastian bertanya kepada Bilal, apakah ia boleh mengajak Katharina mengunjungi mesjid. Berikut ini adalah salah satu contohnya.

Bilal: Das sind alles keine Probleme! ...

'Tidak masalah!'

Hal ini dapat dilihat dari komponen tuturannya, yaitu S: di sekolah sebelum mengunjungi mesjid,P: Bilal mengijinkan Sebastian untuk mengajak Katharina berkunjung ke mesjid, E: Bilal menyetujui Katharina untuk mengunjungi mesjid, A: berupa persetujuan keikutsertaan Katharina mengunjungi mesjid, $\mathrm{K}$ : menenangkan kekhawatiran Sebastian, I: disampaikan secara lisan, N: persetujuan, G: Bilal menyetujui keinginan Sebastian untuk mengajak Katharina mengunjungi mesjid.

\section{Nilai-nilai Karakter dalam Tuturan di Buku WBM}

Dalam tuturan yang terdapat di dalam buku ajar WBM ditemukan sepuluh nilai karakter. Ke empat puluh sembilan nilai karakter tersebut mencakup 10 jenis nilai karkater, yakni (1) religius, (2) toleransi, (3) disiplin, (4) kerja keras, (5) kreatif, (6) demokratis, (7) rasa ingin tahu, (8) menghargai prestasi, (9) bersahabat/komunikatif, dan (10) peduli sosial.

Pertama, nilai religius. Tuturan dalam buku WBM yang mengandung nilai karakter religius sebanyak dua data. Berikut ini adalah salah satu contohnya.

Bilal: In Deutschland gibt es über 2000 Moscheen!

'Di Jerman terdapat lebih dari 2000 mesjid.'

Dalam tuturan di atas Bilal menyampaikan kalau di Jerman terdapat lebih dari 2000 mesjid, padahal mayoritas masyarakat Jerman pemeluk agama non muslim. Hal ini menunjukkan bahwa orang-orang muslim bisa hidup rukun dengan pemeluk agama lain. Nilai karakter religius tersebut diungkapkan dalam bentuk tuturan langsung literal dengan penanda lingualnya über 2000 Moscheen (×lebih dari 2000 mesjid×).

Kedua, nilai toleransi. Ditemukan sebanyak sepuluh data tuturan yang mengandung nilai karakter toleransi. Berikut ini adalah salah satu contoh data yang dimaksud.

Bilal: UnsereMoscheenkannjederbesuchen, egalwelchenGlaubener hat.

'Siapapun boleh mengunjungi mesjid kami, tidak peduli apapun agamanya.'

Dalam tuturan di atas terlihat bahwa Bilal menyampaikan siapapun boleh mengunjungi mesjid. Hal ini menunjukkan bahwa orang-orang muslim bisa menghargai dan tidak melarang orang non muslim untuk mengunjungi mesjid. Sikap 
ini mencerminkan adanya nilai karakter toleransi. Nilai karakter toleransi tersebut diungkapkan dalam bentuk tuturan langsung literal dengan penanda lingualnya egal welchen Glauben er hat ('tidak peduli apapun agamanya').

Ketiga, nilai disiplin. Ditemukan dua data tuturan dalam buku WBM yang me-ngandung unsur disiplin. Berikut ini adalah contoh data yang dimaksud.

Bilal: Esgibtnur ein PaarKleidervorschriften.

'Hanya saja ada beberapa aturan tentang cara berpakaian.'

Tuturan di atas menunjukkan bahwa Bilal memiliki kepatuhan terhadap peraturan yang harus ditaati. Hal inilah yang mencerminkan unsur disiplin. Nilai karakter disiplin tersebut diungkapkan dalam bentuk tuturan langsung literal dengan penanda lingualnya nur ein Paar Kleidervorschriften ('ada beberapa aturan tentang cara berpakaian').

Keempat, nilai kerja keras. Nilai karakter kerja keras yang ditemukan dalam tuturan yang ada di buku WBM adalah sejumlah empat data. Berikut ini adalah salah satu dari data yang menunjukkan nilai karakter kerja keras.

Katharina: Dürfen Mädchen denn in Moscheen rein?

'Boleh tidak anak perempuan masuk mesjid?'

Pertanyaan Katharina tersebut menunjukkan bahwa ia tertib dan patuh pada berbagai ketentuan dan peraturan, karena itu ia menanyakan mengenai boleh tidaknya perempuan masuk mesjid. Ini menunjukkan bahwa ia berupaya untuk mentaati peraturan yang berlaku di masjid dan hal ini merupakan cerminan karakter kerja keras.

Kelima, nilai kreatif. Terdapat dua data tuturan di buku WBM yang menunjukkan adanya nilai karakter kreatif. Berikut ini adalah salah satu contoh dari data yang dimaksud.
Katharina: Wir sollten uns Notizen machen!

'Kita harus mencatat!'

Pernyataan Katharina tersebut menunjukkan bahwa ia berpikir dan menyatakan sesuatu untuk menghasilkan bagaimana caranya supaya anak-anak yang baru saja mengunjungi mesjid dapat mengingat hal-hal apa sajakah yang baru saja mereka cermati di mesjid tersebut. Tuturan yang dikatakan Katharina merupakan ekspresi bahwa ia memiliki nilai karakter kreatif. Nilai karakter kreatif tersebut diungkapkan dalam bentuk tuturan langsung literal dengan penanda lingualnya adalah semua kata dalam pembentuk tuturan, yaitu Wir sollten uns Notizen machen! ('Kita harus mencatat!')

Keenam, nilai demokratis/emansipasi. Terdapat empat tuturan dalam WBM yang mencerminkan nilai karakter demokratis. Berikut ini adalah salah satu dari data tersebut.

Bilal: Na klar! Frauen dürfen genauso in die Moschee wie die Männer.

'Tentu saja! Sama seperti anaklakilaki, anak perempuan juga boleh masuk mesjid'.

Pernyataan Bilal tersebut yang menyatakan bahwa wanita pun juga boleh masuk mesjid menggambarkan bahwa Bilal menilai sama hak dan kewajiban para wanita dengan pria. Tuturan inilah yang mencerminkan bahwa Bilal demokratis. Nilai karakter demokratis tersebut diungkapkan dalam bentuk tuturan langsung literal dengan penanda lingualnya adalah Frauen dürfen genauso in die Moschee wie die Männer ('Sama seperti anak laki-laki, anak perempuan juga boleh masuk mesjid').

Ketujuh, nilai Rasa Ingin Tahu. Ada enam data dalam tuturan di buku WBM yang masuk dalam katagori nilai karakter rasa ingin tahu. Berikut ini adalah salah satu dari data tersebut. 
Sebastian: (neugierig)Ich hab keine Frauen gesehen.

'(ingin tahu)Aku tidak melihat seorang perempuan pun.'

Dalam tuturan di atas terlihat bahwa Sebastian ingin mengetahui mengapa ia tidak melihat seorang perempuan pun di mesjid. Hal ini merupakan penanda dari rasa ingin tahunya.

Kedelapan, nilai menghargai prestasi. Sejumlah enam data dalam tuturan di buku WBM, mencerminkan adanya nilai karakter menghargai prestasi. Berikut ini adalah salah satu contoh diantara ke enam data yang dimaksud.

Katharina: Das war wirklich total super, Bilal!

'Tadi itu hebat banget, Bilal!'

Terlihat dari pernyataan Katharina di atas bahwa ia mengakui pengalamannya mengunjungi mesjid merupakan hal yang hebat. Bentuk tuturan ini menunjukkan nilai karakter menghargai prestasi.

Kesembilan, bersahabat/komunikatif. Ditemukan enam data dalam buku WBM yang mencerminkan nilai karakter bersahabat/ komunikatif. Berikut ini adalah salah satu diantara data yang dimaksud.

Sebastian: (mit Freude) Sag mal, Bilal, können wir nicht auch wie Katharina mitnehmen?

'(dengan gembira) Katakan Bilal, bolehkah kami juga mengajak Katharina?'

Tuturan tersebut mengandung nilai karakter bersahabat/komunikatif, karena terlihat bahwa Sebastian menyatakan keinginannya untuk mengajak Katharina mengunjungi mesjid. Bentuk tuturannya adalah tuturan langsung literal, dengan penanda lingualnya können wir nicht auch wie Katharina mitnehmen? ('bolehkah kami juga mengajak Katharina?').

Kesepuluh, nilai peduli sosial. Terdapat delapan data dalam tuturan di buku
WBM yang mencerminkan nilai karakter peduli sosial.Berikut ini adalah salah satu dari data tuturan yang dimaksud.

Bilal: Das sind alles keine Probleme! ... 'Tidak masalah!'

Pernyataan Bilal menunjukkan bahwa ia berusaha memberi bantuan kepada Sebastian dengan cara menenangkannya. Hal ini menunjukkan nilai karakter peduli sosial. Bentuk tuturannya adalah tuturan langsung literal, dengan penanda lingualnya semua kata pembentuk tuturan, yaitu Das sind alles keine Probleme! ('Tidak masalah!').

\section{SIMPULAN}

Dalam buku WBM terdapat empat jenis tuturan, yaitu tuturan asertif, tuturan direktif, tuturan komisif dan tuturan ekspresif. Tiap jenis tuturan mempunyai bentuk tuturan yang berbeda yaitu tindak tutur langsung literal, tindak tutur tidak langsung literal, tindak tutur langsung tidak literal dan tindak tutur langsung tidak literal. Dalam buku WBM penutur dan mitra tuturnya adalah anak-anak sekolah dasar, sehingga bentuk tuturannya sebagian besar adalah tuturan langsung literal.

Fungsi tuturan dalam buku WBM yaitu (1) tuturan asertif untuk menyatakan, menyarankan, mengeluh, melaporkan dan mengidentifikasi, (2) tuturan direktif untuk meminta dan bertanya, (3) fungsi komisif untuk berjanji dan menawarkan, (4) fungsi ekspresif untuk memuji, menyambut dan menyetujui.

Nilai-nilai karakter yang diungkapkan tuturan dalam WBMada sepuluh jenis, yaitu (1) religius, (2) toleransi, (3) disiplin, (4) kerja keras, (5) kreatif, (6) demokratis, (7) rasa ingin tahu, (8) menghargai prestasi, (9) bersahabat/komunikatif, dan (10) peduli sosial. Nilai-nilai karakter ini juga memuat pembelajaran interkultural berbasis agama. 


\section{UCAPAN TERIMA KASIH}

Artikel ini diangkat berdasarkan penelitian yang dilakukan pada tahun 2014 dengan anggaran DIPA FBS UNY. Oleh karena itu ucapan terima kasih diucapkan kepada FBS UNY. Ucapan terima kasih juga diucapkan kepada reviewer yang telah membaca, mengoreksi dan memberi masukan terhadap artikel ini.

\section{DAFTAR PUSAKA}

Buâmann, Hadumod. 2008. Lexikon der Sprachwissenschaft. 4. Auflage. Kröner: Stuttgart.

Hoffmann, L (Hrsg). 2000. Sprachwissenschaft. Ein Reader. 2., verbesserte Auflage. Berlin/New York: Walter der Gruyter $\mathrm{GmbH} \&$ Co.KG.

Linke, Angelika et.all. 1996. Studienbuch Linguistik. 3., unveränderte Auflage. Tübingen: Max Niemeyer Verlag.

Marzuki. 2011. "Prinsip Dasar Pendidikan Karakter Perspektif Islam" dalam Buku Pendidikan Karakter dalam Perspektif Teori dan Praktik. Yogyakarta: UNY Press.
Sudaryanto, 1993. Metode dan Aneka Teknik Analisis Bahasa: Pengantar Penelitian Wahana Kebudayaan secara Linguistis. Yogyakarta: Duta Wacana University Press.

Sudrajat, Akhmad. 2010. Tentang Pendidikan Karakter. Diunduh dari http://akhmadsudrajat.wordpress.com/2010/08/20/ pendidikan-karakter-di-smp/ pada tanggal 10 April 2011.

Suharjana. 2011. "Model Pengembangan Karakter melalui Pendidikan Jasmani dan Olahraga" dalam Buku Pendidikan Karakter dalam Perspektif Teori dan Praktik. Yogyakarta: UNY Press.

Suyanto. 2010. Urgensi Pendidikan Karakter. Diunduh dari http://waskitamandiribk,word press.com/2010/06/02/ urgensi-pendidikan-karakter/tanggal 14 April 2011.

\section{Sumber Data}

Cepni, Halim et.all. 1996. Wir Besuchen eine Moschee. Ein Erkundungsbuch für die ganze Klasse.3.Auflage. Soest: Landes Institut für Schule und Weiterbildung. 